\title{
Connecting Talent to Technique An Actor's Exploration of Connecting Back to Their Roots
}

Madeline Hintz

Follow this and additional works at: https://researchrepository.wvu.edu/etd

\section{Recommended Citation}

Hintz, Madeline, "Connecting Talent to Technique An Actor's Exploration of Connecting Back to Their Roots" (2018). Graduate Theses, Dissertations, and Problem Reports. 5810.

https://researchrepository.wvu.edu/etd/5810

This Thesis is protected by copyright and/or related rights. It has been brought to you by the The Research Repository @ WVU with permission from the rights-holder(s). You are free to use this Thesis in any way that is permitted by the copyright and related rights legislation that applies to your use. For other uses you must obtain permission from the rights-holder(s) directly, unless additional rights are indicated by a Creative Commons license in the record and/ or on the work itself. This Thesis has been accepted for inclusion in WVU Graduate Theses, Dissertations, and Problem Reports collection by an authorized administrator of The Research Repository @ WVU. For more information, please contact researchrepository@mail.wvu.edu. 


\title{
Connecting Talent to Technique
}

An actor's exploration of connecting back to their roots

\author{
Madeline Hintz \\ Thesis submitted to the College of Creative Arts \\ at West Virginia University \\ in partial fulfillment of the requirements for the degree of \\ Master of Fine Arts in \\ Acting \\ Laura Hitt, M.A., Chair \\ Lee Blair, M.F.A. \\ Jules Malarcher, Ph D. \\ School of Theatre \& Dance \\ Morgantown, West Virginia 2018
}

Keywords: Acting, Theatre, Sondheim, Musical, Voice, Assassins, Sara Jane Moore, Thesis, Performance

Copyright 2018 Madeline Hintz 


\author{
Abstract \\ Connecting Talent to Technique \\ An actor's exploration of connecting back to their roots \\ Madeline Hintz
}

This paper is a reflection of my experience performing the role of Sara Jane Moore in the musical Assassins. To work through this role and honor the simplicity of the comedy, I needed to divulge my insecurities that stem from my past musical theatre and comedic experiences. Working through my past and my time here at WVU, the realization of how personal tensions affected my work made the role of Sara Jane Moore the most challenging experience of my graduate school education. The increased awareness of my resistance to new acting and voice techniques allowed me to grow and develop, so that I began to implement them. Additionally, I started to have a greater appreciation for my pre-graduate performance skills. This allowed me to integrate the past and present skills with greater ease in my stage work. Throughout this paper I reflect on my training in WVU's MFA Acting program, my challenges with comedic and musical theatre roles, and the thesis role that I had previously assumed I knew. 


\section{DEDICATION}

The author wishes to dedicate this paper to her late grandfather, Douglas Hanson. Thank you for introducing me to jazz, to the theatre, and for taking me to the circus. 


\section{ACKNOWLEDGMENTS}

The author wishes to acknowledge the hard work and dedication of her thesis chairperson, Professor Laura Hitt. Not only was the author supported throughout the rehearsal and writing process by Laura, but through these past three years of training. In addition to her thesis chair, Madeline would like to thank her director for this production, Professor Lee Blair, for showing her how to relax into the comedy. Madeline would also like to thank Dr. Jay Malarcher for his support and comments throughout her career at WVU and the excellent training all three gave on and off stage.

Madeline would like to acknowledge the continual love and support from her friends: Joseph Gay (Booth), Analisa Condon, Luke Schaffer, and Lindsey Steffes.

The author would like to thank her partner, John Meszaros, for his unwavering support in her academic achievements. He encouraged her, stood by her, and allowed the author to fully become herself.

Madeline would be remiss if she did not mention her parents and brother who have supported her through every lesson, rehearsal, and performance. They have pushed the author to be the best that she can be, gave her the courage to step on stage, and let her practice her comedy at the dinner table.

Finally, the author would like to thank her home town of Baraboo, WI. Growing up there was the greatest privilege of her life. 
TABLE OF CONTENTS

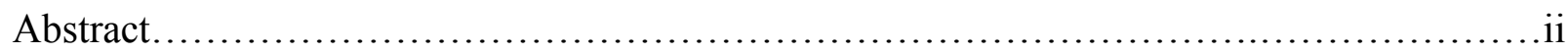

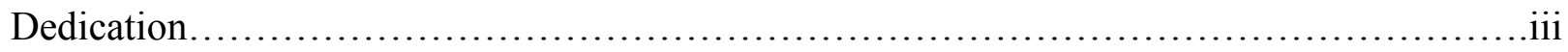

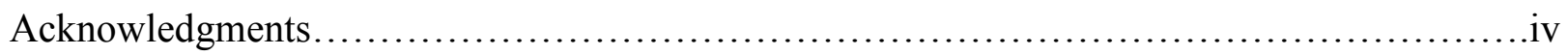

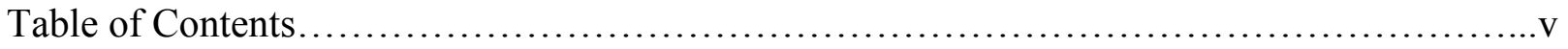

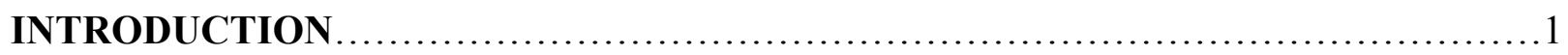

CHAPTER 1 First Steps ......................................................... 10

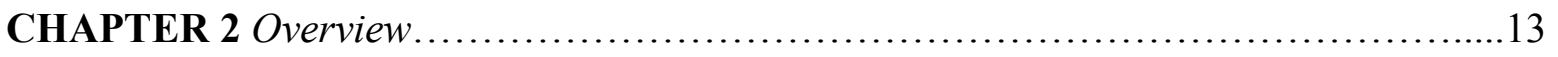

CHAPTER 3 Breakdown .................................................. 16

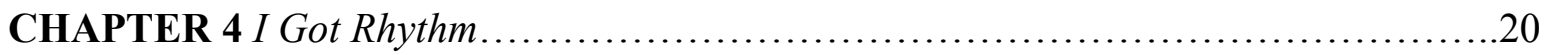

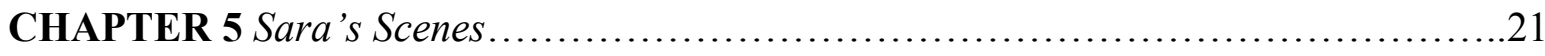

CHAPTER 6 The Real Sara Jane................................................25

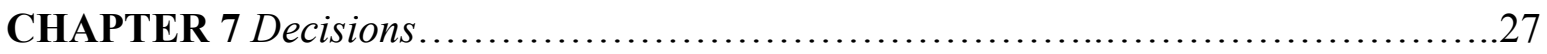

CHAPTER 8 The Final Year.............................................. 30

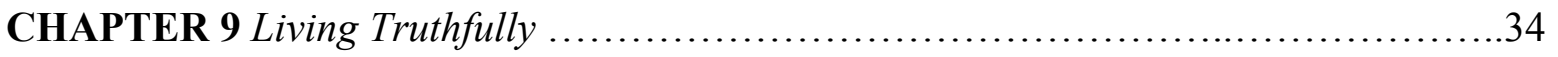

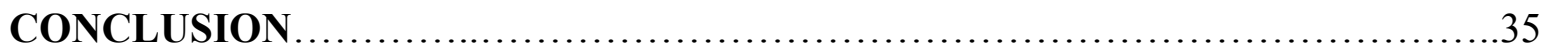




\section{INTRODUCTION}

Since as far back as I can remember I have been called a "ham." I was always doing my best to make people laugh and I had the best audience for it. My mom, dad, and little brother laughed at almost everything I did, whether I pretended to get smashed by stationary machinery, changed the lyrics of church hymns, or challenged the clowns at the Ringling Bros, Barnum \& Bailey Circus.

I was lucky enough to be born in the town of Baraboo, WI, where the Ringling Bros. were originally based in 1884 and continued to return to until it folded. Their presence in our town seeded my desire to be funny. That desire was indulged by the community; comedy lessons from the clowns were just a phone call away. We had season tickets to the circus and went multiple times during the summer. When it was off-season, the local clowns came to our school, the local theatre, and sometimes my own grandpa's house. I grew up laughing. Laughter was, still is, my favorite sound of anyone's voice. I never took the "ham" label as an insult; "ham" was the highest compliment. This label changed as my humor changed throughout the years, but I have always surrounded myself with people who love to laugh as much as I.

I consistently give credit to my voice getting me into theatre, but that's the short story. It started with the clowns and those who introduced me to them. My grandpa Doug, friend and fan of all of the local clowns, was somewhat of a town celebrity. It seemed that he knew every person he ran into and was a long-standing member of our local theatre guild. But for me, his celebrity came from the way he could make anyone laugh and my mom was his spitting image.

I have this vivid memory, when I was four or five (my brother could barely walk), my dad took us to the theatre. My mom was rehearsing the play Dancing at Lughnasa. I remember watching her on stage, soaked in the lights, in her olive-green dress, and she was laughing. As I 
sat there, staring up at my mom, I realized that this is what I wanted to do.

It wasn't just my maternal grandfather and mother who were involved with theatre. Aunts and uncles welcomed me into the community with tons of tips, songs, and audition outfit suggestions. My grandparents on my other side taped live musicals and sent them from Florida for me to watch; my godparents took me to musical after musical. I still have the t-shirt from the production of Annie that my godmother directed in 1993. Having a family with all of this theatrical experience came with strong suggestions on how to better myself and, from my colleagues I met through musical theatre, it started with the voice.

As I mentioned earlier, I liked to make people laugh. As a good Catholic, as a child I attended Catholic mass twice a week. The best way to make people laugh then was to change the lyrics to hymns. It was hard work writing and then practicing changes from "when I get into your kingdom" to "when I get hit in the dingdong." My brother encouraged me and I assume my parents didn't think it was too harmful as they were still hymns. But the giggling attracted the nuns and soon after I became a song leader where I had to sit alongside Father Vosen and the varying altar boys. I still practiced my comedic lyric changes at home for Sunday mass, but I also was able to use these Wednesday song leading sessions to work on my voice. During that time our organist suggested I take private voice lessons.

Now having multiple suggestions of private voice lessons, my mom decided to contact different musicians she knew at our local community college. They recommended starting with classical voice training. At the age of twelve, I was introduced to Deanna who would become my voice teacher of seven years and one of my greatest influences to this day. Along with teaching me how to better my voice, Deanna taught me how each step I took could be crafted to better fit my acting career, each show could teach me something new, and uncover the intense drive in my 
personality. During that time, I started to go to different singing competitions in Wisconsin and then throughout the Midwest. I started auditioning for productions at the professional theatre in the next town over. I loved it. I loved the competition and the game that came with theatre. This game I now know as casting, but at the time I loved guessing which role I would be because of my voice type, changing my techniques I had learned to fit roles, and picking repertoire to fit the show. Deanna might not have been the best person at the casting "game" but she knew how to get me where I needed to be for the audition.

Because of my competitive spirit, I clung to Deanna throughout my early training and looked to follow in her footsteps. During my high school years, I held on even tighter and preached the importance of training classically and how these roots would help one to sing in different styles. These beliefs proved true time and time again; but all of my high school colleagues thought the classical training was unimportant and distracted from becoming a Broadway star. While they were all moving out to L.A. and NYC after high school, I intended to get my degree in musical theatre. I would show them that training was imperative for a successful career. I planned to mimic Deanna's educational path of: undergrad, time off to work, followed by graduate school, all completed before the age of 30 .

However, I knew that classical training was the key not from my voice lessons, or the operas and musicals I was in and attended, but from the clowns. These clowns have been successfully making me laugh for my entire life and they trained to do it; I knew my training would lead me to the same success.

I continued with my training at North Central College (NCC). My competitive personality was equally met by my fellow musical theatre students. We helped prepare each other for auditions, we spent nights off working on our own shows, and then headed into the Chicago 
theatre district to get cheap student tickets. At NCC my training began in music and focused on theory and composition. With my background in piano and voice, my advisors encouraged me to start with something I knew. This path challenged me but helped me later when I continued to study voice, develop ensembles and direct/produce student musicals.

During that time, I met an amazing vocal coach, Tom Dymitt. He taught me how to correctly belt, although I still didn't know how to correctly articulate the method. He motivated me like no one else. While I grew extremely fond of the excitement of Chicago and the theatre produced there, the college did not cultivate my creative spirit. At NCC only one theatre class was available due to conflicts with music classes. All we had was "Play a Day". While I loved the concept of reading a play a day, followed by a discussion, I wanted to dive into acting training like my friends. I felt like I was on the second tier because I couldn't take the acting classes that everyone else had. My beloved coach, who had helped me to sound better than I had ever sounded before, supposedly was the coach for people they didn’t think would go far.

The productions I was cast in were said to be the "bad" productions with lower budgets and less audience. I was stunned, but as I had never been in plays I thought maybe it was due to my lack of training. I was extremely proud of the work I had done at NCC. However, the more I played my casting "game", I noticed there was not a space for me. All of these rumors I heard from supposed friends seemed to be coming true. The competition was too stressful for me, especially as I found friendships to be more important than theatre. Tom admitted he wouldn't be able to take as many students due to a new teaching post at a different university. With possibly losing my favorite teacher, I looked into possible employment. It was at that time that my parents asked me to transfer schools so that I could be closer to them. While I had been at NCC, they had moved to North Carolina. This offered an opportunity to start over and find a new place 
where I could be challenged.

I wondered, “Maybe I could do something else?". I found theatre people using the motto: If you can picture yourself doing something other than theatre, do it. So, when I transferred to Appalachian State, I decided to focus on theatre education. I would still be able to take the theatre classes I wanted to, find out about auditions, partake in clubs and organizations, but would have a fall back plan. Something that I could do on the side or in case acting professionally didn't work out.

I question now how this self-doubt came to be. I was, and still am, malleable. I allowed myself to be deterred by colleagues who would be happy to have one last person to be competing with and lost track of my plan. I was disappointed in myself, my lack of planning when I chose a new university, and my decision to change majors. However, my ego was still there, even bigger than from my first year of college. I also expected the students to have the same competitive streak as that of my previous colleagues. So "whatever" was my motto. I liked this campus and I liked this town. I didn't care if the theatre here was good or bad, but I was going to take theatre classes.

I took an equal load of theatre for performance and education classes. I loved them both and while the education classes were more rigorous, I finally trained in theatre; however mediocre it may have been. I took basic acting. My professor Joel used me as his example and I happily obliged. This put me at an advantage as he directed my monologues in class and helped me to use my stories to personalize them while the other students needed to do this work at home. I worked with him multiple times as my director after this class. The Stanislavski techniques were extremely beneficial for connecting not only to my monologues but to my songs as well. One of my education professors, Dr. Chris Osmond, came to see me in a local production of Godspell. 
Afterwards he said, "We'd love to gain you as a teacher, but you belong there. I had never seen you like that, it was like you were a different person." I called the university that next morning to change my major.

I didn't change my major to theatre performance, but general theatre. I was better supported and felt more confident about my acting after a few basic classes, but my education classes with Dr. Osmond gave me a fire for social justice that I felt I could use in my theatre work. I created a plan that allowed me to take the same classes as the theatre performance major and go further with optional classes, i.e. dialects, stage combat, and advanced acting. In addition, Appalachian State endowed me with some of my closest friends. As students we were motivated to perform the kind of theatre that we were interested rather than just choices driven by the faculty. We asked our department to produce productions that challenged the audience's perspective, pushed the theatrical team, and in general, were more inclusive. We had two professors, Derek Davidson and Keith Martin, who encouraged us to create organizations that would reflect our passions for new kinds of productions.

While my training in the acting classes was basic at Appalachian State, the training through the productions and the choice of productions engendered new ways to create. I was spoiled in that way. I spent the summer and winter breaks energized, looking forward to the next season and being given new opportunities. I started to look into casting, to see where I might fit, and be completely surprised. I felt teachers setting new bars for me in my performances, but on stage rather than in the classroom.

In addition to productions, the training I received allowed me to create my own work and to start organizations. It seems unparalleled. My friends were just as determined as I. We filled out paperwork to make the groups official early in the morning, attended classes, and main stage 
rehearsals. But in our late night rehearsals from $11 \mathrm{pm}-2 \mathrm{am}$ we worked on the productions we felt would make a change in the world. We started the Appalachian Musical Theatre Ensemble and Appalachian Women's Theatre Troupe. These were the groups I mentioned earlier. I was on fire. I felt my plan working flawlessly but there was one minor hitch, my training.

As I said previously, still my acting training was basic. I finally was getting some of this training I longed for, but I could tell I needed to be pushed harder. My professor, Keith Martin, teased me with the nickname, "Seabiscuit", the race horse. I took it in stride, as a compliment. I wanted to be the best, truly a complete theatre practitioner that would make a difference in any community. My movement and voice professors skimmed the surface of what they said we should receive. Our movement focused on the Alexander Technique, but we never connected it to our acting. The same happened in our voice classes. We never worked out of a book or through a specific voice technique. I continued to work with my private vocal coach, Linda Larson. She was confused as to why I sang one way and spoke in another, why I did not breathe properly, and why I couldn't correctly articulate where I placed my belt resonance. Soon after this enlightening coaching session, where we reviewed everything I wasn't taught, Linda suggested that I go to grad school, "to be taken seriously."

Almost five years later ... and I'm still working on the definition of what "to be taken seriously" actually means. In the past, that meant no more musical theatre and, if allowed, no more comedy. I was still passionate and ready to tackle the professional theatre world but felt jaded. How was it that I completed my degree and knew so little about my craft? I could make productions happen, lead meetings, rehearsals, and speak to potential donors, but I didn't possess the technique that I thought I had been studying since my very first voice lesson when I was twelve. I knew that I needed to push myself harder. Graduate school was required. It was clear to 
me, even if not by anyone who I worked with during my undergraduate career. I needed to better understand my craft, the techniques, and how to integrate them.

I moved to Chicago after undergrad to work as the casting intern for The Goodman Theatre. Here my "game" jumped to a new level and actually learned the work that went into casting a production. I spent a great deal of time in auditions, meeting with directors about their ideas, and helping actors prep for their roles. While running lines, I was able to pick the brains of Brian Dennehy and Nathan Lane, both of whom told me to work hard, keep my nose to the grindstone, take big chances and make bigger mistakes. I became friends with countless actors who said the same thing and reminded me that while this profession takes hard work, it's doable; just don't take it personally. I learned this through my time in casting where in the audition room directors would give reasons as to why one actor wouldn't get a role and it gave me insight on myself.

Immediately before leaving for Chicago, I auditioned for grad school at SETC after having a horrible attempt the year before at Unified Resident Theatre Association (URTA) auditions. I went from still being in school and getting one callback, to finishing a show, working on a reading, my internship starting in one month, while receiving 12 callbacks! What a difference one year can make! I'm still convinced it was my haircut. By that I mean I was trying to be a "serious" actor and according to my definition from Chapter 2, that meant dropping the musical theatre. That meant chopping the long hair to something more my type, stop with the A-line dress and character shoes, spend more time on my monologue than on my song. However, many callbacks didn’t mean that each school would fit my criteria for "seriousness." I asked each school whether I was required to perform in musical theatre. The answer I wanted was, "no." But the answer that enticed me the most came from only one professor. It was like this professor knew me. That musical theatre was something I wanted to stay away from but couldn't. 
Professor Lee Blair from WVU told me that musical theatre was not the main focus in the graduate program, but they had a BFA musical theatre program. He said that wherever the overall casting fell, then that would be the obligation. That was the temptation I needed to hear and it kept WVU surprisingly a top contender.

From that point on, every time I forgot about WVU or my sights strayed to a different program, something pulled me back. WVU flags and license plates were suddenly everywhere in North Carolina, Appalachian State Mountaineers suddenly turned into the West Virginia Mountaineers, a detour to an audition had me driving past signs directing me towards West Virginia. Submissions in my mailbox at The Goodman had WVU on their resume, and finally, I met a WVU grad student, Stephanie. I met her at an audition and she overheard me talking about possibly going to grad school. She was so complimentary of the program that I was sold. When Jerry McGonigle, the head of the program, asked me to visit campus I could only meet in Chicago, but I was going to make that happen. I wanted a second chance to really get to the training that Appalachian didn’t provide for me.

As I proceeded with my education and chose to come to WVU, for some reason I lost my original drive. I lost what my real goal was and how I wanted to continue my education and my training to be seen as this "serious" actress. This phrase continues to come up throughout my thesis and I have found the definition to mean "I judge myself". I have used this long-standing casting "game" as a third eye. Analyzing my acting not through technique but through how I felt the scene or monologue "should" be or sound. Most importantly, I stopped performing for myself. I was making choices based on what I anticipated the audience would like and, in typical clown fashion, would improvise choices based on their response. This anticipation was a block to my learning and ultimately a reason for my need to be serious. Throughout my thesis, I will 
explore my frustrations that stem from my competitive nature, my tendency to anticipate, my comedic background, and how my training here at WVU was completely realized as I went back to my roots in musical theatre and comedy. How the seriousness I was looking for was really a need to please others. It became an inhibitor to connect to my talent and to my technique.

\section{CHAPTER 1}

\section{$\underline{\text { First Steps }}$}

My time at WVU had a complicated start. With my extensive training in voice, I thought it was my strongest feature. I signed up not only for our required voice class with Professor Hitt, but also for private voice lessons through the School of Music with Professor Rob Chafin. Both professors were wonderful and encouraging, but I kept feeling that my lessons were contradicting each other. Chafin worked with me on my onset of breath, and how not to hold my breath before producing sound. We specifically worked with different techniques that I have previously used in my voice lessons that, while their focus was breath, mostly focused on sound, at least as I perceived it. I believed that my vocal training was a great asset but was quickly becoming my greatest weakness.

I had deeply ingrained vocal habits and tensions in my body that intensified as I was made aware of them. In addition to my resistance to change, my singing voice training was becoming more of the same, deeply reinforcing my old habits, concurrently I was trying to release my habits of listening and monitoring myself in my speaking voice classes. When these habits and tensions were brought up by either professor, I took it to be criticism and used my knowledge of my voice to attempt to fake what was needed. This perceived criticism made me hate my voice. I already felt negatively about doing musical theatre, but this made it clearer that somehow musical theatre ruined me as an actor. While I could improve in other aspects onstage, I thought 
it was near impossible to let go of my vocal tensions and habits. It seemed that I would never make improvements of my old and ingrained vocal techniques.

I knew I needed to make a choice. I needed to focus on our acting voice classes with Laura and really dig deep into what she was saying, take time to notice and work to release my tensions, do the exercises in class and outside, and incorporate this training into my daily routine. It was eye opening to recognize my tensions and habits while starting with the body, breath, thought, and image. Finally, I started to allow the breath and sound to drop in rather than force the process, which was a habit of mine from the start. My second year I had lots of work to do. During my first year, I felt improvements in my acting and movement classes. However, ironically I realized that I needed to start all over again with my voice. I worked over the summer re-reading sections from Patsy Rodenburg's The Actor Speaks and Kristin Linklater's Freeing the Natural Voice. I worked on their specific exercises and also other exercises that we explored in voice class. When I came back my second year, classes with Laura were different. I learned to trust that she wanted to encourage and challenge me to improve my speaking and overall vocal abilities. I now understood the connection between noticing and releasing tensions and using my free and full voice.

This release of tensions in my body also came with releasing tension in my mind. I recognized my drive and need to be better would come if I would put the work in and use the different sets of tools each professor was giving me. I loved that I could use my breath or work with tensions in my body to connect to my emotions. I was open to trying different things with actors and working off their behaviors. I felt almost completely open and free, but there was something continuing to hold me back. I continued to use my casting "third eye" and felt that I was forgotten about when it came to productions. 
Halfway through my graduate training program I was able to learn from each production I was involved with in different ways, but when I looked to my second semester of my second year, I saw a musical that I had already done and a Shakespeare play in which I probably would not be cast. What is more, I was scared. The musical, Pirates of Penzance, is a show that I love. The question was: would I go back to old habits? I didn't want to undo this freedom that I had finally found, but the idea of working on that show tempted me. What was the harm of doing a show twice? I just completed performing in Trojan Women for a second time.

I was proud of myself throughout the process of working on Pirates of Penzance. I felt that I could still be funny, sing, and not fall back or rely on old habits that I had worked hard to be aware of. However, I still judged myself and worried that I was not able to really connect with musical theatre roles like I could with straight theatre, more specifically drama. The strides I felt I had made during my second year and throughout Trojan Women when it came to voice and the character were tested while working on Pirates of Penzance. I continued to revert back to pleasing the audience but could just as easily drop that act and focus on the other actors on stage. I made improvements, but I figured my thesis would be in the dramatic realm to really help cement the things I was taught throughout my time here at WVU.

To my surprise, the drama in my thesis production was not the type of drama I expected. I was cast as the comedic relief in a musical. I did not know what to think. It was not that I didn't want to work on the production, but again, I was concerned that I would revert back to old habits and forget my training. It was true that I felt I didn't lose my new techniques during Pirates of Penzance portraying the role of Ruth. I felt this was due to excellent direction and consistently being in class, but Assassins was more contemporary. I felt that the contemporary aspect of the show had potential to push me back into my old habits. The different styles I worked on allowed 
me to release tensions, but with the contemporary comedy I thought I may lose all of the work I put in to this release of tensions. However, I would need to learn about Sara Jane Moore to really understand what my training here at WVU would mean and how I could incorporate the training into any kind of production.

\section{CHAPTER 2}

\section{Overview}

My connection to the circus starts before lights are up with Assassins. The first sounds are of that of a circus or festival. Percussion, bright brass, and deep bass reflect the sounds of circus marches like those written by John Phillip Sousa. However, in Sondheim's true fashion, the music quickly hits darker tones. The addition of guitar and less of the bright brass immediately makes this change. This opening number introduces some of the assassins and uses this circus/carnival theme as a game, egging the assassins to step up, take the gun, and play. The first player and our first assassin is John Wilkes Booth.

"The Ballad of Booth" has the Balladeer introduce Booth. The scene allows the audience to sympathize with Booth in a way that doesn't typically happen. Booth explains why he killed Lincoln, but the Balladeer brings to light the facts. Those facts help the audience understand that due to the assassination of a President who during his lifetime possessed mixed reviews by the public, after his death became seen as one of the greatest Presidents of the United States. After this song, all of the assassins meet in a limbo/bar scene.

The abstract nature of the book allows for the assassins to gather together across historical periods, in turn it makes a strong comment about the influential nature of the assassin on historical perception; one aspect builds upon the other. In this limbo scene, Booth speaks to two assassins. He offers them the opportunity they have to change the world in the same powerful 
way that he did. This is important to note because the music directly before this scene reminds the audience the fact that Booth glorified Lincoln's reputation, when it's possible if Lincoln had not been assassinated that his perceived legacy would have been very different. But to these assassins who are all gathered for a drink, Booth becomes a leader.

While in the bar, Booth suggests to Zangara to attempt to assassinate the President-elect Franklin D. Roosevelt. This leads into the next song “How I Saved Roosevelt.” Heavily influenced by a traditional American march, this song describes how the crowd felt that they had helped to save Roosevelt. The American-style march, typical of John Philip Sousa or Edwin Eugene Bagley, is structured in a similar fashion to the French military march. In addition to being known for earlier key changes, the American style march became popular through the live performances presented by and made more popular by The Ringling Brothers and Barnum \& Bailey circuses. Live march music performances played throughout the circus which popularized this music genre.

This song led to another Americana style of music, the barber shop quartet. "Gun Song" is preceded by scenes with Emma Goldman and Leon Czolgosz and the meet up of Sara Jane Moore and Squeaky Fromme setting up the one assassination and two attempted assassinations. This song glorifies the assassin and what the assassin can do but is specifically from the assassin's point of view. As I will mention later, “Gun Song” is the first introduction to Sondheim's unique style of irregular meter.

“The Ballad of Czolgosz" tells the audience, through the lyrics of the Balladeer, Czolgosz's assassination story. Rather than glorifying Czolgosz, the song reflects his quiet nature by not giving him anything to say or sing during this song.

This turns into Byck's monologue where Byck does nothing but talk. Sondheim doesn't 
disappoint with his connection to different styles in American music with his duet between Squeaky Fromme and John Hinckley. This song reflects styles in the late 70's and early 80's which is when both attempted their assassinations.

The next scene is with Moore and Guiteau that is a catalyst for both assassins. Moore is unable to hit her target, foreshadowing her assassination attempt, and Guiteau does not get what he wants. After he is turned down by Moore, Guiteau meets James Garfield and after being denied the position of the Ambassador to France, Guiteau assassinates the President. This leads into his hymn "I am Going to the Lordy" where he eventually walks himself up to his own hanging.

The episodic nature of the script now leads to Squeaky and Moore and their combined assassination attempt. Although this is not historically accurate, they were very close in actual time and date. The combination of their assassination attempts did not deter from the story and added the opportunity to compare the assassins and their personalities. This gave an opportunity for the audience to immerse themselves into the time of these assassination attempts and to understand the extreme personalities of the time. If one was live for these attempts they would've been easily reminded of the rocky nature of the United States after the resignation of President Richard Nixon and the appointment of President Gerald Ford.

Sam Byck's second monologue immediately follows and he announces his plan to fly a plane into the White House. He speaks about his own "American Dream" not being realized and leads all of the assassins in "Another National Anthem." The Balladeer attempts to make the assassins see the positives in their lives, but the assassins force him off stage. In the revival in 2004 and our production, the Balladeer transforms into Lee Harvey Oswald. Booth meets Oswald in the book depository and with the help of the rest of the assassins they convince him 
that to connect with others and having a meaning in life he must kill John F. Kennedy.

After the assassination of Kennedy, the citizens sing "Something Just Broke" to recount what they were doing when they heard the news and share how their country has now been changed forever. Jarringly, this leads immediately into the finale where the opening, “Everybody's Got the Right” is reprised. This quick change in mood solidifies Sondheim's decision to reprise the opening number as the finale and reflects the assassins' inability to learn from their mistakes.

\section{CHAPTER 3}

\section{$\underline{\text { Breakdown }}$}

Although the musical Assassins dwells in a darker, more serious realm, like his productions of Sweeney Todd: The Demon Barber of Fleet Street and Into the Woods, it does not immediately show his well-known percussive and irregular metered style through the entirety of the score. Sondheim is known to have one of the most unique and diverse artistic styles in musical theatre. Sondheim uses melodic changes, stops, patter, syncopation, and dissonance throughout his music. These elements challenge his listener's ear while also reflecting the dark storylines. There is an obvious connection to his musical and dramatic intensity that makes a Sondheim musical very much in contrast and unique in style in comparison to a traditional golden age musical. His musicals share a type of subject matter and musical style that make them easier for a listener to distinguish from his more popular musicals, such as Sunday in the Park with George and

\section{Company.}

And as should be clear from the outset, 'sound,' in Sondheim's case, means much more than music... an analysis of how a character comes to act or think is just as 
important in exploring Sondheim's sound as is a melodic or harmonic analysis.

Thus, we cannot understand his sound by considering the music alone...We must draw upon music, theater, and film to begin to enter Sondheim's sound world. ( Swayne, How Sondheim Found His Sound, 3)

His musicality is shown through his use of melodies which nod and are influenced by classical and popular Western melodic writing (Purin ii). While Assassins does not immediately show Sondheim's typical "sound", it does show his connection to these popular Western styles. Including folk (predominately Stephen Foster), barber shop quartet, and Sousa style marches. Moore's solo in "Gun Song" and the entire song of "Another National Anthem" is where the audience hears Sondheim's "sound."

One section of this song features Moore as she tries to tell the audience about the gun she bought. She searches through her purse for the gun, unable to find it for a while. Her melody is interrupted by her frustration with not being able to find it and the tangent of finding her shoe instead. The interruptions and tangents are conveyed through both the pitch and rhythm of the melody, which ultimately make the musical phrases irregular. As mentioned in the second chapter, the use of irregular meter in "Worst Pies in London" may reflect the dubious psychological state of Mrs. Lovett, which also may be true of Moore in "The Gun Song." (Purin 193)

My analysis of the text during the "Chicken Scene" or the first scene with Squeaky Fromme did not help ease my apprehension with falling into old habits. Moore did not seem like the type that would be able to kill a president. Sondheim's interpretation confused me. How did her aim miss President Ford? The goal for my approach while working on this production was to work 
through the text, fold in the historical context, and layer on the music. While Moore is a real person, the play is a fictional re-telling of what happened. This is made apparent in the "Bar Scene" with all of the assassins joined together in the bar and the introduction of Booth planting the seed in their minds of the future assassinations.

In the analysis of the text of "Bar Scene", Moore is described as desirable, obsessed with her looks, and wealthy enough to carry a fifty-dollar bill in her purse. While her sporadic characteristics in other scenes made her seem goofy, this bar scene allowed Moore to take herself seriously, although it is the most abstract scene in the play. Research shows that Moore lived an affluent lifestyle. After five failed marriages and five children, one would assume that she would have a fairly middle-class lifestyle. In fact, she was quoted multiple times saying she lived in poverty (Malcolm, A1). However, she continued to wear designer clothes and sent her youngest child to private school. Moore lived as a suburban housewife throughout many of her marriages but after her divorce was known to spend and live outside of her means which I directly connected to her pulling out a fifty-dollar bill in the "Bar Scene".

Moore worked as a bookkeeper for the People in Need (PIN) program and as an agent for the FBI. While working for the FBI, her job was to observe and get into close circles with radicals like those in the leftist terrorist group, the Symbionese Liberation Army (SLA). While observing the SLA, Moore started to be persuaded by and agree with their viewpoints. In time, she became a member and started working with the terrorist group rather than simply serving as an informant for the FBI. An associate, who also belonged to both groups, led Moore to believe that she was being followed. As her obsession with the SLA grew and became clearer to others, the FBI let her go. From various articles it appears that she became extremely unstable, asking her friends to supply her with guns. She was convinced her fellow colleagues were following 
her. She also states that she had no intention of taking a shot at the president until that very day when she shot him (Malcolm, A1). However, during her 1975 interview with Ben Williams, reporter for KPIX News San Francisco, Moore was the antithesis of loony (Moore).

Throughout her interview with Williams, Moore explained how she was prepared to shoot the president and was extremely angry that she missed. She claims that she was with an FBI agent when she bought the .38 used to shoot the president, but the FBI had confiscated her .44 the day before. These details are confusing as Moore's personal recounts of the events leading up to the attempted assassination differ from those of the FBI. In her on-camera interview with Ben Williams, Moore claims to have been planning Ford's Assassination since her infatuation with the SLA but was deterred as Lynette "Squeaky" Fromme made her attempt two weeks earlier. Moore described her attempt and events leading up to it with charm and a cold disassociation to the event. This was absolutely shocking to me as it seemed she was living a suburban lifestyle inside the prison. She claims that prison was not treating her well but showed Williams around the facility while smiling with the charm of her Southern hospitality, pointing out enjoyable activities that they have on campus.

From her interview, Moore comes across as determined and malicious rather than loony, but inconsistencies in her story and reports of her paranoia showed me the loony side that her friends described and the way she was portrayed in the script. Moore's attempt to be taken seriously connected me to this role. While she was portrayed as someone who was goofy and couldn't shoot her own gun, her honesty and serious nature would be underneath the surface. The first scene perfectly establishes her seriousness and obsessive traits along with her wealthy background and status. 


\section{CHAPTER 4}

\section{$\underline{I \text { Got Rhythm }}$}

In my experience with musical theatre, musical rehearsals begin the same time as scene work rather than divided first music rehearsals. Professor James Mitchell, the music director for this production, focused on individual music first then added full chorus. With my previous experience with James working on Pirates of Penzance, I anticipated this move and I was sure to have an analysis of the text and research about the character. My preference when working on musical theatre is to approach the character through the music then layer on the text. For this production, in an attempt to avoid old habits, research was introduced first. As a benefit to my personal process, I was not as concerned with my musical parts as it was not as heavy as a singing role as I was used to.

As the production went on, it was clear that my role had the extremely challenging syncopation and rhythm that Sondheim is known for through "Gun Song". The song was not a vocal challenge for me as I grew up working with close harmonies. However, it was the rhythms that challenged me. This was more complicated than the rhythm of a good joke or scene as musical rhythms are a more complicated form of math. The counting and precision of notes becomes more specific with music, especially with composers like Sondheim. His ability to use more complicated, mathematical phrases was unnatural to me but gave me the opportunity to grow with precision. Because of my desire to focus on research I was not off book for this song when we started blocking. In addition to the rhythms, I was required to pull different items out of my purse until I finally found my gun. I typically learn music through repetition but the only way I could work on this section of the song was to work on it alone. Eventually, the only way I 
would be able to sing through at the correct rhythm, I kept it straight on the beat rather than syncopated; was to get off book and change my path to incorporate text and song. Additionally, I worked with looking for objects in my purse which gave me enough time in between phrases so that I was able to learn the correct timing. However, my director would argue that the mathematical rhythms of the music were now completely in my body.

Other difficulties I had with the music had been starting on the key change which had me humming my note that I picked out from another character's musical phrase while they continued to sing. I did this until tech when I finally trusted myself; knowing that I knew the pitch. This is something I do frequently as I am a perfectionist and have a fear of making mistakes in front of people. This fear is one of the reasons I hold my breath after I inhale which makes it more difficult to produce a full and restricts my sound. I worked to stop judging and molding myself into something that forced me into self-destruction.

The work on "Gun Song" with the quartet helped me with this learning process. The barber shop quartet section of this song was a challenge because of singing and breathing with the group. I did not have opportunity to hold my breath or judge myself because I would not have been able to work with the group and hold the notes that were not in my control. Again, trusting myself and my colleagues was a huge part of the musical process and letting Sara Jane Moore come to life through song helped me to see the ease in the comedy, song, and character.

\section{CHAPTER 5}

$\underline{\text { Sara's Scenes }}$

\section{Bar Scene / "Limbo"}

The Bar Scene is a fantasy where all of the assassins meet. The audience sees the different personalities and, in certain situations, the reasons behind their assassinations of their respective 
presidents. Through blocking the scene, Moore starts by listening to Guiteau's description of his book, and while in the script it states that all are to respond, none of the actors did. This was an opportunity in the show to show Moore's Southern charm while getting Guiteau's attention. Guiteau notices Moore for the first time and chases her around the stage and over to her seat with Squeaky. It is here that Moore discusses her bright red lipstick. This is an interesting choice in color for Moore as it has the opportunity to represent her feminine qualities and blood. Squeaky tells Moore off and tries to deter her from using the lipstick by the inclusion of disgusting details of how it was made and the animals that it was tested on. Moore's lack of interest in the way the make-up was made showed me that she cared more about her looks rather than animal rights or whatever Charlie (Charles Manson) had to say.

\section{Chicken Scene}

Moore enters to meet Squeaky Fromme and finds her smoking a joint. To this planned meet up, Moore brings KFC chicken to share, TAB soda, and her eagerness to kill. "This scene is not funny" I continued to say to myself throughout the entire process, from audition to closing night. This was supposed to be the big scene for Squeaky and Moore, but I could not find the point of it. The scene is simple: Moore walks in and the duo discuss their lives and discover their interconnections. This leads them both to the realization that they should kill the sitting president. This was the most challenging scene that I worked on in graduate school. Not because the text was particularly difficult or there was a challenge with blocking. Instead, my concern was that I would play a caricature which I was striving to change to more authenticity. Moore was not a clown in this circus. In addition, eating fried chicken and drinking pop was an uncomfortable character choice as it was established in the previous scene that she would never touch either of those things. However, this is what the text said to do, and I needed to relinquish 
my power struggle with the text and let Moore eat. Moore does say that she wouldn't eat the chicken unless she absolutely needed to after being busy with work, taking care of her child, and/or getting her nails done. I was focused on the wrong part of the scene and created struggles for myself that weren't necessary.

Eating was not the difficult part of this scene, it forced me to attempt to eat fried chicken as Sara and not make it a comedic turn. "This scene is not funny" took a new meaning. In the beginning of rehearsals, the feeling was this would be a comedic relief moment but I could not find the humor in it. Now I realize that for the scene to be funny, it needed to be serious. Sara wanted to be taken seriously which is what made her comedic. As the actor, I did not need to do anything to make it funny besides say the words and mean them. Something that helped me get there was the terrible bacterial sinus infection I contracted two weeks out from tech week. I was feeling ill a few weeks before but was able to push through until I could hardly move. I continued to go to rehearsal and work, eventually having to call in my understudy so that I could go home to rest. When I was back, I still was weak and had to work the scene. The most I could do was to just say the lines, with hardly any inflection. Laughs! People were laughing like they had never before laughed at this scene. It was glaring; a message to hear. That was all Moore wanted. And this became one of my biggest lessons in grad school: just say the lines.

\section{Guiteau Scene}

After "Gun Song", the next time Moore came on stage was to practice shooting. The script describes that she has a terrible stance and that continues to miss her target. Moore had trained to shoot a gun in the FBI. I overanalyzed the scene; questioning why she would be written this way. However, in the last scene I learned not to question the text, but to believe it. I shook the gun over my head to get the bullets into the chamber, pointed my toes in towards the target, and shot 
the gun. Most important, I took the time to remind myself to speak the character's truth.

Working with Patrick J. Clarke, who played Charles Guiteau was an absolute pleasure. The blocking was difficult to get down with shooting the gun and the grab of the arm but after working with Professor Jessica Bishop, our fight choreographer, and rehearsing the moves together, the scene gelled. He was more than willing to meet up and rehearse while being respectful in an awkward chase scene. The description of Moore was always one that was unattractive but for a woman who has had five husbands she had to be somewhat alluring. I would not say that it made the scene harder but I had to question how Guiteau would be attracted to Moore after so many people called her fat and matronly with five chins (Epstein et al.). While watching Moore in her prison interview with Williams, the answer came to me. She was not attractive but her polite attention to Williams made her seem completely interested in every word he said. I knew that a young naiveté would suit Guiteau after speaking with Patrick about his research. He mentioned how Guiteau had many lovers, even while married, and he died of syphilis. They were the perfect match in the sense that Guiteau would go for anyone who gave him attention and Moore was too polite not to give him the attention he craved. When he did not take the hint that she was not interested she accidentally shot him in the ear, continuing to establish the fact that with all the help in the world Moore would not be able to shoot any target.

\section{Attempted Assassination of Gerald Ford}

Guiteau finishes his song where he is hung and in the dark the audience hears a shot and a howl which happens to be Moore shooting her dog. When Moore realizes that her dog has been shot she doesn't burst into tears. She just casually says her catch phrase in the production: "Shit." In first reading the scene, I did not understand why it was necessary. It didn't really make sense until Squeaky and Moore made their assassination attempt on Ford. However, the scene 
establishes Moore's disinterest or care for living things including her own pet and child. Moore did not bring her own child to the assassination but it is known that she abandoned her five children and only took care of her youngest, Fredrick (the character in the play is named Billy). (Malcolm, A1) Squeaky, a character who left her family at a young age to join the cult of Charles Manson, is stunned with the carelessness of Moore, along with the fact that she would bring her pet and child to an assassination. Moore was more concerned about the state of her possessions at home and whether her pet might ruin her furniture or car. In the end, she turns her gun on her son simply because he won't stop crying over his melting ice cream. The scene continues with the appearance of President Ford and his approach to Squeaky and Moore. Unbeknownst to him, they are waiting to assassinate him. Quickly afterward more mayhem results: Squeaky's gun doesn't go off, and Moore fumbles and drops all of her bullets. Oddly enough, she then just throws them at Ford.

\section{CHAPTER 6}

\section{The Real Sara Jane}

In addition to over thinking the comedy, the work with Marissa was an extremely challenging aspect of this production. One night after rehearsal she approached me, exasperated and said, "I don't know how you do it every night! Acting is hard!" I was stunned because she had to have been acting while she sang but she must've seen it as something different. She was young, and I understood her more than she knew; I had just forgotten what it was like. She didn't have the automatic comedic timing that came with some of the others I read with during the callback, but she had pure talent that grabs your attention on stage and off.

I felt constrained to say each line with the same timing. For if I paused or did something different, she would jump to pick up the line thinking I missed it. Finally, I started running lines 
with her for our scenes before we started the show, just to reassure her that I knew them. We finally started to get a pace down by closing night. However difficult, I am thankful for her. It was a realization of my own bad habit of not being consistent with my scene partners. I have had trouble with other partners in my graduate school career not being consistent, jumping cues, and going the complete opposite direction of how the scene was rehearsed. It made me recognize that if I was more consistent in the beginning of the rehearsal process the discoveries I made in my own rehearsal time could be introduced later in the rehearsal process allowing my scene partner to recognize these changes.

Some changes, however, are welcome throughout the process and necessary when scenes rely on them. I am not talking about character changes but props that are required in the scene. I have eliminated gluten from my diet and was required to eat friend chicken during the "chicken scene.” My director, Professor Lee Blair, had no problem letting me eat rotisserie chicken for the scene but it seemed to be an issue with props. I ended up reintroducing gluten into my diet for an easier time eating the chicken and was given chicken throughout the process. However, it was extremely difficult for me to eat this chicken every night. I have always found fried chicken disgusting but knew that Moore would not apologize for her consumption of this greasy mess even after Squeaky told her how disgusting it was. As the run came to an end, the chicken got older and colder. I wasn't expecting an amazing meal, but props disappointed me during this production when it came to the food issues.

Additionally, I was required to have a TAB pop to drink along with my chicken, an absolute nightmare for me as I have, what I call, a burping disease. Anything that is too acidic or carbonated I cannot consume and I needed to drink it right before I sang in "Gun Song". This caused me more stress than burping during the song but waiting off stage before I entered to sing 
was extremely frustrating. Not really because of the pop but because of my own perfectionist traits. I was so worried that I would be able to sing this song, my one song in the show, perfectly. It was such a small thing and so petty, but I felt I needed it to practice. I didn't get the pop until opening night and had to make sure only to take one sip. Looking back, I knew that I should've faked it. The struggles with food need not have happened but something about Moore's dialogue made it seem like she would be more interested in the food than she was with Squeaky and her story. However, I need not have worried about Moore and her accuracy when it comes to the real Moore and the scripted character.

\section{CHAPTER 7}

\section{Decisions}

Given Moore's connection to Charles Manson in the script, my research started with him and the cult that famously disrupted the '70's. However, the more research I did, the more I noticed that Squeaky Fromme was a central person in his life and Sara Jane Moore was not mentioned. Unfortunately, due to my naiveté, I believed the script. It took me longer than I would like to admit to recognize that Moore had nothing to do with Manson, other than the fact that they did both reside in Charleston at the same time. However, their paths never crossed. What other inconsistencies would I have to wade through while navigating this role?

It was difficult to find information on Moore. As a failed assassin, there wasn't much character analysis of her. She wasn't a member of a cult like Squeaky Fromme not to mention she attempted her assassination two weeks after Fromme's attempt. While researching Moore, the first thing to pop up was her 2007 interview that followed her release from prison. I avoided it ads it was year later but heard my fellow cast members talking about the interview. They spoke about how she was a sweet little old lady. Curious, I watched, while questioning how a person 
who attempts to kill could be described as sweet. After watching the video, I felt that my colleagues were exaggerating. Sara Jane Moore was polite. She possessed a Southern charm that I only learned of after I moved south of the Mason-Dixon line. In fact, she was not sweet at all. She sent sharp, quick daggers to the interviewer when she disliked the phrasing of questions. This person giving an interview was not the same goofy person in the script. I took note but moved on. Was it possible she was hardened in prison?

In an interview that Ford did about his attempted assassination Moore seemed to have been forgotten about. A failed sloppy second in comparison to the Manson crazed "Squeaky" Fromme. Moore reasoned that given Ford was appointed by a crook rather than elected to the presidency, he did not possess legitimate power as the president. She mentioned that there were other people who she looked up to who should be in power but never gave specific names. Moore did not want conspiring charges to fall on them but as she did not mention the names, these are only assumptions. Her willingness to sacrifice her own freedom was for these unnamed people.

During the time of the attempted assassination, Moore was said to be living in Danville, CA where she lived with her son, Frederick and fourth husband Carmel. However, she and Carmel were on the outs and she had moved into San Francisco's Mission District. There is some speculation as to where Moore was residing during this time and it seems that she was in both places. Many reports say she was coming from the Mission District to attempt the assassination, but Moore herself said she was coming from Danville. Moore's life was filled with secrets and lies. She reported facts to one news outlet and would change those facts while speaking to another. Even with her accounting jobs, and specifically for PIN in San Francisco, Moore gave a fake social security number. It was there that Moore became associated with the leftist radical 
group the SLA. Due to that association, she was recruited to be an informant for the FBI.

However, as her time continued, she felt more connected with the SLA. She said that she needed to cut ties with the FBI to better serve the SLA. This connection led her to be interviewed by the secret service the night before her attempt to assassinate Ford questioning if she had intentions to use her leftist radical connections to cause an attack on the U.S. or the president while he was in San Francisco. ${ }^{1}$

Moore disputes this accusation, but after her interview with the secret service her .44 was confiscated and she was charged with possession of an illegal firearm. That did not deter her attempt. She bought the .38 Smith and Wesson that she used to fire at President Ford that morning. In her first letter to the author of her biography, Taking Aim at the President, she described that on the day of the attempted assassination, she drove from Danville loading the gun as she drove. During this time, she was concerned about being late to pick up her son from school. She wasn't suspecting she would be late because she would be in jail, but because of the attention and recognition she would receive (Spieler 136) (Malcolm, A1). Moore did not have time to practice with the new gun and if she would've she would notice the gun shot up and to the right. Moore reported herself to the New York Times that she didn't feel she needed to practice. She said, “If I would've had my .44 I would've hit him!” (Malcolm, A1)

Her lying, the inconsistent stories, and her arrogance made me believe that she had mental issues that would allow her to be easily influenced by other SLA members and why her friends would describe her as loony. It is another reason why her interviews came off as a mélange of

\footnotetext{
${ }^{1}$ Wead, Doug. "Gerald Ford Assassination Attempts." Online video clip. YouTube. National Geographic. 16, February 2013. Web. 7, January 2018. 
aggressive, sweet, and scary qualities. However, she many different doctors cleared her (Malcolm, A1). During her interview with Ben Williams, a KPIX broadcast journalist from 1975, Moore seemed to brag about how she was cleared by many different psychologist and psychiatrists (Moore).

While she may have been cleared by professionals, I personally looked at Moore and saw someone very sad; someone who longed for attention that she was not given by her family. Was her lack of ties to her family, including the majority of her children, a reason why she felt she could sacrifice herself for a cause that she felt would change the entire world? From what Moore said in interviews, I didn't see her wanting to change the world for the better. She did not see Ford as an evil man. Rather, in her mind, it was wrong that a man gained the power of the presidency through unlawful means. I was in disbelief. This was hardly a reason to take a life.

\section{CHAPTER 8}

\section{The Final Year}

I felt Sara Jane to be weak; caring too much about what people thought about her. Cleared by medical professionals? I did not believe it. I had higher standards for my characters. I expect them to be more decisive and arrogant, unlike what I expect from myself or the people with whom I surround myself. However, I knew that mindset was not going to work for me as an actor approaching this role. Sara believed she was right. She believed that this was something she needed to do. I was not going to apologize for the actions she took. Moore continues to say that she was wrong, that she had gotten into something that was way over her head. In an interview from 2015, she continued her inconsistencies and delusions by stating how she has changed, but taking a life then was nothing compared to now (CNN).

I recognized a person that was lost, who continued to look for guidance and followed people 
in the wrong places. However, that was not in the writing. The character that was written gave me as the actor opportunities to make choices on where to be more volatile, a quality that was seen in the interviews with Moore that I watched during my research phase. In the play, the way Moore interacts with Guiteau would give the actor perfect opportunity to become angered or have the mood swings that were found in research. However, knowing Moore's relationship with men, I knew that she would not act that way even with men she was not interested in. She would make the same choice that a bully would; to attack someone who she assumed to be younger or weaker than herself. This is how I was able to justify with the play turning the gun on the character of Moore's son, Billy.

Moore did not have a son named Billy. In fact her youngest and known to be favorite was Frederic. However, knowing this connection and how close Moore was to Frederic, I knew that it would have to be a high-pressure situation to turn her on her own son. Before Moore attempted to assassinate Ford, the pressure would be mounting. Billy's tantrum could not stop Moore. In the script, she turns the gun on Billy. However, I knew that if Moore chose to do something, to make a challenge or an attempt, that decision would be very serious. I made the decision to aim for the head.

However, during this production, as the actor I felt I did not "aim for the head." Looking back, I see where I could have made bigger choices and been more consistent in the changes Moore went through. They were not typical as the script was not typical. While Moore's storyline did progress in an arc as a normal storyline would, I knew from the research Moore would fit something episodic. I felt that because of the nature of this show, I could have made choices bigger to fit the story and the stage. I continued to attempt to make scenes funny but I kept feeling forced. Saying to myself "it wasn't my job." 
In my past, I felt that one of the hardest parts was to play into one's type. Typically, I felt that it was my job to make the scene funny, to make people laugh out of the dull scenes. This role was no exception. However, I wanted to show how different Moore was. I wanted to reveal her serious side. I wanted Moore to be taken seriously, just like I wanted to be taken seriously as an actor. I needed to learn the honest communication that truly makes comedy funny. I have to admit there was disappointment when I saw that I would not be playing a serious role, but through all of my research, I did indeed find that Moore was serious. Her quirks were what the audience laughed at not her. That decision to not make her a "caricature", but rather a closer portrayal of the woman was one reason why I did not make bigger choices. It felt unnatural to portray her as someone who was, for lack of a better term, real.

If there is one thing I have learned in my graduate school career, it is that it does not need to feel like a big choice to be a big choice. In fact, the choices that are smaller to me have made the biggest impact on my training. I have felt more connected to the characters that $\mathrm{I}$ have been portraying and have had easier access to connecting to the research. When it comes to working with other actors, I noted many times throughout my journaling that it was easier for me to look past their acting and see them as the character. I have the tendency to not only look for the perfection from myself but from other actors as well. This has made it difficult to work with others in the past as I have high expectations not only for myself but for the ones I am working with as well. I have found myself to be disappointed with others, especially during the rehearsal process. I believe this is the reason I was having a tough time with the actress who played Squeaky Fromme.

As I started to connect with the research about Moore, the easier it was to relax around Squeaky and work off of her behavior. Working with a young actor so intimately was a huge 
challenge for me as I previously mentioned. However, what was most important for me was to take Squeaky's behavior in stride. We did not do any of the repetitions that I had studied in our Meisner Technique class. She would not start that acting work until her following semester. Regardless, I took my previous Meisner training and applied it to observe this actor's behavior on and off stage. I worked to get to know the actress personally. When starting the Meisner acting technique, one starts with basic exercises to connect with ones reactions and listening abilities. Repeating what one's partner is saying to see if one is really listening and connecting to their behavior. Sanford Meisner said "the foundation of acting is the reality of doing." When approaching a character one must "live truthfully under imaginary circumstances." Again, Meisner is saying that although the character and situation is imaginary the actions have to be truthful. In addition, the actor needs to be focused on their partner and work off of their behavior. During this working process, I observed the actor portraying Squeaky work through her process and noticed that when a choice was made, it would stick no matter my reaction. With the consistency of her choices and the requested line-through runs before each production, I felt that it was difficult for me to work off of her behaviors because they were already predetermined. Instead, I felt the connection with her when I changed a choice I would typically make or if either of us went up on a line. Although interesting, this was a tricky game especially if it would be a change I made. If that was the case, I found that the younger actress would try to cover for me, thinking I was making a mistake. What I appreciated about the actress and her undeniable talent was her willingness to jump in, help, and work together. She is an extremely willing partner and while it was a tough decision on how to proceed working together, she taught me a lot about myself and about working off of someone who had not been trained before in the Meisner Technique. 


\section{CHAPTER 9}

\section{Living Truthfully}

"Living truthfully under imaginary circumstances" was a quote I repeated it throughout my training, but most importantly throughout this rehearsal process. I knew Moore, or what I could find out about her, like the back of my hand. However, since I found this character to be so much more different than the real-life Moore, I knew that to connect with her completely I would need to work with the others on stage; to connect with them more truthfully to make this character really come to life on stage.

As I worked on this role and utilized the Meisner Technique, I reflected through these years of training and questioned how I have changed. I found myself letting go of my habits, not just habits I found while studying in the classroom but ones I discovered in the rehearsal hall during this production. The tensions and the holding I found with my breathing habits and voice techniques were coming from my personal insecurities of not feeling good enough and competing with my castmates. But my biggest change was to remain physically and mentally open and responsive. Throughout these three years, I learned to relax into roles instead of forcing them. I found it similar to what I learned with my breath awareness, I began to let images, sound, text, and eventually, the character to drop in to my entire being.

Throughout my process here at WVU, I had been resistant. When I came here, I was not a "Seabiscuit" as my undergraduate professor claimed. I had the stamina and wanted to learn, but my head was clouded with my "serious" need. Eventually, I recognized my need was to please other people. I did not want to stop doing musicals or comedy, but I thought that to have a successful career I would need to do other things. Not just become well rounded but to completely cut out the things that made theatre commercially viable. They were in fact the very 
things I loved about doing theatre. My entire plan to graduate from college, get a prestigious internship, work, finish my MFA (not an MA or other training program, this plan was very particular) before thirty, and move to back to Chicago was not for me after all. My training here taught me about myself, and the value of going back to basics. I thought I wasn't getting pushed in my training through this role, but in the end to portray Sara Jane Moore pushed me more than I could have imagined. The role of Moore pushed me harder and further than any of the roles I had the opportunity to portray. I finally learned the technique that I needed to connect to my talent.

\section{CONCLUSION}

Throughout this process, I learned to let my past inform my decisions. My education, undergrad and grad, pushed me to research Moore from every angle. The inconsistent facts that were reported about Moore, and by Moore, I used to inform her sporadic nature and overwhelming personality. To work with new actors is extremely challenging but the techniques I learned while in classes I could apply without the other actor's experience or knowledge with the technique. This gave me confidence and reminded me that I knew what to do. This process pushed me to look past my insecurities and accept my process. I finally accepted who I truly am and that helped me to fully realize my training and my potential. Each breath I took on stage needed to be my own before I could differentiate to Moore's breath. My analysis of each scene changed as I worked and connected to Moore. I learned to empathize with Moore. Her feelings of injustice in the political climate are reflected in me now but I could never imagine taking lethal action. I used that injustice to understand her willingness to put herself in that kind of trouble and to send the country into that kind of turmoil.

I related to the comedic moments that were in the text for Moore and didn't work against 
them. The work I put into the comedy came to me like it always had: through the clowns. As I rehearsed, I thought of my time at Circus World of Happy the Clown, and my grandfather. I stole something from those memories. There is a bit with a water gun and when Happy shoots the gun the water doesn't come out, but when he shakes it above his head to check for the water, it spills onto him. When Moore cannot make a shot on the KFC bucket, I shook the gun for me as a reminder of where I came from. I finally let myself make decisions although they may not have been the "right" choices. Grad school gave me training, confidence, and permission to be myself. 


\section{WORKS CITED}

Aarons, Leroy F. “The Emergence of Sara Jane Moore.” Jfk.hood.edu/collections. Washington Post, 28 Sept. 1975. Web. 29 Oct. 2017.

Berry, Cicely. Voice and the Actor. Virgin Books, 2009.

Block, Geoffrey, and Stephen Sondheim. "Assassins.” American Music, vol. 11, no. 4, 1993, p. 507., doi:10.2307/3052548.

CNN. "Why she tried to kill the president." YouTube, uploaded by CNN, 22 Sept. 2015. Web. 26 Sept. 2017, https://www.youtube.com/watch?v=y4k4WF72dqk\&t=1s

Epstein, Edward, and Chronicle Washington Bureau. "Ford Escaped 2 Assassination Attempts /

Both Happened in California -- One in Capital, Other in S.F." SFGate, San Francisco Chronicle, 12 Jan. 2012, https://www.sfgate.com/news/article/Ford-escaped-2-assassinationattempts-Both-2481771.php .

Lambert, Laura. "Symbionese Liberation Army.” The Encyclopaedia Britannica. 3 Aug. 2017. Web. 27 Jan. 2018

Landis Purin, Peter Charles. "I've a voice, I've a voice, I've a voice": Determining Stephen Sondheim's Compositional Style Through A Music-Theoretic Analysis of His Theatre Work. Diss. University of Kansas, 2011. Lawrence: Kansas, 2011. Web. 19 Feb. 2018.

Lewis, Uncle Dave. "Screamers - Frederick Fennell, Eastman Wind Ensemble | Songs, Reviews, Credits." AllMusic, www.allmusic.com/album/screamers-mw0001351671.

Linklater, Kristin. Freeing the Natural Voice: Imagery and Art in the Practice of Voice and Language. Drama, 2007.

Malcolm, Andrew H. "Accused Ford Assailant Has Led a Tangled Life." nytimes.com/archives, 
The New York Times, 24 Sept. 1975. Web. 11 Nov. 2017

Meisner, Sanford, and Dennis Longwell. Sanford Meisner on Acting. Vintage Books, 1987.

Moore, Sara Jane. Interview by Ben Williams. KPIX San Fransico. 1978. Web. 13 Sept. 2017, https://archive.org/details/caolaam_000079

Rodenburg, Patsy. The Actor Speaks: Voice and the Performer. Methuen Drama, 2005.

Sondheim, Stephen. Finishing the Hat: Collected Lyrics (1954-1981) with Attendant Comments, Principles, Heresies, Grudges, Whines and Anecdotes. Knopf, 2011.

Spieler, Geri. Taking Aim at the President: The Remarkable Story of the Woman Who Shot at Gerald Ford. Palgrave Macmillan, 2009.

Turner, Wallace. "Sara Jane Moore Indicted on Coast." nytimes.com/archives, The New York Times, 25, Oct. 1975. Web. 11 Nov. 2017. 